Original Article

\title{
Treatment Non-Compliance in Bipolar Affective Disorder Patients: A Study from a Tertiary Care Centre in Nepal
}

\author{
Sandip Subedi ${ }^{1}$, Kamala Paudel ${ }^{2}$ \\ ${ }^{1}$ Associate Professor, Department of Psychiatry, Universal College of Medical Sciences, Bhairahawa \\ ${ }^{2}$ Lecturer, MMIHS, Kathmandu, Nepal \\ Corresponding Author:
}

Dr. Sandip Subedi; Email: sandipsubedi@hotmail.com

\section{ABSTRACT}

Background: Treatment Non-compliance is a major challenge in the treatment of Bipolar Affective Disorder as it can give rise to lots of unwanted consequences. Therefore, understanding various reasons for noncompliance and taking steps to reduce it is a key step in minimizing the unwanted consequences. Thus, This study was done to identify the pattern of non-compliance in patients with Bipolar Affective Disorder.

Methods: This was a cross-sectional study including 76 patients who attended Psychiatry OPD of Universal College of Medical Sciences. Socio-demographic datasheet, Datasheet for various factors related to noncompliance, Morisky 8-Item Medication Adherence Scale (MMAS-8) and Descriptive summaries of sociodemographic and contributing factors for all patients were used to record the data.

Results: Out of a total of 76 patients, males (55.2\%) were slightly higher than Females. Mean age of participants was $35.78 \pm 12.25$ years. About $76.8 \%$ of the patients were non-compliant. High non-compliance was seen in age below 40 years (48.7\%), male (52.6\%) and duration of illness up to 15 years (78.9\%), having up to 3 pills (44.7\%) and having previous treatment history (60.5\%).

Conclusion: Treatment non-compliance was very high in patients with BPAD. Appropriate measures need to be taken care of to reduce non-compliance.

Keywords: Bipolar Affective Disorder, Non-Compliance, Nepal

\section{Access this article Online}

\begin{tabular}{|c|c|c|}
\hline Quick Response Code & Website: & $\begin{array}{l}\text { How to cite this article in } \\
\text { Vancouver Style? }\end{array}$ \\
\hline & www.jkahs.org.np & $\begin{array}{l}\text { Subedi S, Paudel K.Treatment Non- } \\
\text { Compliance in Bipolar Affective } \\
\text { Disorder Patients: A Study from a } \\
\text { Tertiary Care Centre in Nepal. } \\
\text { Karnali Academy of Health } \\
\text { Sciences 2020;3(1):1-8. }\end{array}$ \\
\hline & $\begin{array}{l}\text { DOI: } \\
\text { https://doi.org/10.3126/jkahs.v3i1.28458 } \\
\text { The DOI will be functional after the issue is fully } \\
\text { published online as well as in printed version. }\end{array}$ & $\begin{array}{l}\text { Received: February 15, } 2020 \\
\text { Accepted: April 6, 2020 } \\
\text { Published Online: April 8, } 2020 \\
\text { Conflict of Interest: None } \\
\text { Source of Support: It is supported by } \\
\text { the Research Grant from UCMS, } \\
\text { Bhairahawa }\end{array}$ \\
\hline
\end{tabular}




\section{INTRODUCTION}

Treatment Compliance is defined as "the extent to which a person's behaviour corresponds with agreed recommendations from a healthcare provider". ${ }^{1}$ Study shows that treatment non-compliance ranges from $20 \%$ to $60 \%$ in patients with Bipolar Affective Disorder (BPAD). ${ }^{2,3}$ This is a serious issue because it can give rise to a number of consequences including poor clinical outcomes, functional impairment, impaired quality of life and higher costs of care..$^{2,4,5}$ Multiple factors like past history of nonadherence, longer duration of treatment, poor insight, fear of medication side effects and cluster B personality traits ${ }^{2,3,6}$ have important relationship with noncompliance. Understanding these factors can help us to formulate plans to improve compliance in our context. Though there are lots of researches done in BPAD, literature search doesn't show any research that addressed the problem of Non-compliance in BPAD in Nepal. Thus, this study was done to identify the pattern of noncompliance in patients with BPAD.

\section{MATERIALS AND METHODS}

This was a cross sectional study done in Psychiatry OPD of Universal College of Medical Sciences (UCMS), Bhairahawa Nepal. Patients diagnosed as a case of BPAD, visiting the Psychiatry OPD with a care-taker, above 18 yrs age, under treatment for at least 6 months and currently euthymic were included in the study. Patients were excluded from the study if not reached euthymic state, under intoxication with psychoactive substances, Intellectual Disability patients, having other co-morbid psychiatric illnesses, patients donot give written informed consent, not accompanied by caretakers. A total of 76 patients were enrolled in the study by disproportionate stratified random sampling method. Socio-demographic data sheet, Data sheet for various factors related to non-compliance, Morisky 8-Item Medication Adherence Scale (MMAS-8) ${ }^{7}$ and Descriptive summaries of socio-demographic and contributing factors for all patients were used to record the data. The study duration was 6 months i.e. from 1st June 2018 to 30th Nov 2018. Ethical Approval for the study was obtained from the Institutional Review Committee, UCMS. The data were kept confidential and were used for research purpose only. Chi square test was applied for categorical variables.

\section{RESULTS}

Out of Total 76 patients, males (55.2\%) were slightly higher than Females. Mean age of participants was $35.78 \pm 12.25$ years. Majority of the participants (88.2\%) were married, maximum patients (61.8\%) were unemployed though majority (85.5\%) were literate. This research report revealed that more than half of 
the patients (55.3\%) were from joint.

Maximum patients (65.8\%) were from low income family. (Table 1.)

Table 1. Demographic Characteristics of Diagnosed Mental Illness ( $=76)$

\begin{tabular}{|l|l|l|}
\hline Variables & Frequency & Percentage \\
\hline Gender & & \\
Male & 42 & 55.2 \\
Female & 34 & 44.8 \\
\hline Age group & & \\
$\leq 20$ years & 4 & 5.3 \\
$21-39$ years & 38 & 50.0 \\
$40-59$ years & 29 & 38.2 \\
$60+$ years & 5 & 6.6 \\
\hline Marital & & \\
status & 67 & 88.2 \\
Married & 9 & 11.8 \\
Unmarried & & \\
\hline
\end{tabular}

\begin{tabular}{|l|l|l|}
\hline $\begin{array}{l}\text { Occupationa } \\
\text { l status } \\
\text { Employed } \\
\text { Unemployed }\end{array}$ & 29 & 38.2 \\
\hline $\begin{array}{l}\text { Education } \\
\text { status }\end{array}$ & 65 & 61.8 \\
$\begin{array}{l}\text { Literate } \\
\text { Illiterate }\end{array}$ & 11 & 85.5 \\
\hline $\begin{array}{l}\text { Education } \\
\text { level (n=65) } \\
\text { Basic }\end{array}$ & 27 & 14.5 \\
$\begin{array}{l}\text { Secondary } \\
\text { University }\end{array}$ & 25 & 41.5 \\
\hline $\begin{array}{l}\text { Type of } \\
\text { family } \\
\text { Joint }\end{array}$ & 43 & 20.5 \\
Nuclear & 33 & 56.6 \\
\hline $\begin{array}{l}\text { Economic } \\
\text { status } \\
\text { low income } \\
\text { middle } \\
\text { income }\end{array}$ & 26 & 43.4 \\
\hline
\end{tabular}

Table. 2. Level of Medication Non-compliance among BPAD (N=76)

\begin{tabular}{|l|l|l|}
\hline Level of non-compliance & Frequency & Percentage \\
\hline Low non-compliance (high compliance) & 10 & 13.2 \\
\hline Medium non-compliance (Medium compliance) & 19 & 25.0 \\
\hline High non-compliance (low compliance) & 47 & 61.8 \\
\hline
\end{tabular}

The total prevalence of non-compliance among BPAD patients was 76.8\% during the course of their illness. This was further divided into medium (25\%) and high (61.8\%) non-compliance. (Table 2.)

With regards to association between noncompliance and demographic characteristics, there was high non-compliance rate in age below 40 years (48.7\%), male (52.6\%) which is statistically significant ( $p=0.019)$, married $(76.3 \%)$, literate $(77.6 \%)$ which is statistically significant $(p=0.033)$, unemployed (50.0\%) which is statistically significant $(\mathrm{p}=0.047)$, joint family $(44.7 \%)$ and low economic status (55.3\%). (Table 3.) 
Table. 3. Non-compliance by demographic characteristics $(\mathbf{N}=66)$

\begin{tabular}{|c|c|c|c|}
\hline Variables & Compliance n (\%) & Non-compliance n (\%) & $\boldsymbol{P}$ \\
\hline Age group & & & NS \\
\hline$<40$ years & $5(6.6)$ & 37 (48.7) & \\
\hline$\geq 40$ years & $5(6.6)$ & $29(38.2)$ & \\
\hline Gender & & & $.019 *$ \\
\hline Male & $2(2.6)$ & $40(52.6)$ & \\
\hline Female & $8(10.5)$ & $26(34.2)$ & \\
\hline $\begin{array}{l}\text { Marital status } \\
\text { Married } \\
\text { Unmarried }\end{array}$ & $\begin{array}{l}9(11.8) \\
1(1.3)\end{array}$ & $\begin{array}{l}58(76.3) \\
8(10.5)\end{array}$ & NS \\
\hline $\begin{array}{l}\text { Education status } \\
\text { Literate } \\
\text { Illiterate }\end{array}$ & $\begin{array}{l}6(7.9) \\
4(5.3)\end{array}$ & $\begin{array}{l}59(77.6) \\
7(9.2)\end{array}$ & $.033^{*}$ \\
\hline $\begin{array}{l}\text { Occupational status } \\
\text { Employed } \\
\text { Unemployed }\end{array}$ & $\begin{array}{l}1(1.3) \\
9(11.8)\end{array}$ & $\begin{array}{l}28(36.8) \\
38(50.0)\end{array}$ & $.047^{*}$ \\
\hline $\begin{array}{l}\text { Type of family } \\
\text { Nuclear } \\
\text { Joint }\end{array}$ & $\begin{array}{l}2(2.6) \\
8(10.5)\end{array}$ & $\begin{array}{l}32(42.1) \\
34(44.7)\end{array}$ & NS \\
\hline $\begin{array}{l}\text { Economic status } \\
\text { Low income } \\
\text { Middle income }\end{array}$ & $\begin{array}{l}8(10.5) \\
2(2.6)\end{array}$ & $\begin{array}{l}42(55.3) \\
24(31.6)\end{array}$ & NS \\
\hline
\end{tabular}

${ }^{*} \mathrm{p}<0.05$ = significant, $\mathrm{NS}=$ not significant

Table 4. Medication Non-compliance by Treatment Related Factors (N=66)

\begin{tabular}{|c|c|c|c|c|}
\hline Factors of & Non-compliance & Compliance & Non-complia & $p$ \\
\hline & $\begin{array}{l}\text { Duration of illness } \\
\text { 1-15years } \\
16-30 \text { years }\end{array}$ & $\begin{array}{l}7(9.2) \\
3(3.9)\end{array}$ & $\begin{array}{l}60(78.9) \\
6(7.9)\end{array}$ & NS \\
\hline & $\begin{array}{l}\text { Comorbidity } \\
\text { Yes } \\
\text { No }\end{array}$ & $\begin{array}{l}3(3.9) \\
7(9.2)\end{array}$ & $\begin{array}{l}16(21.1) \\
50(65.8)\end{array}$ & NS \\
\hline 索 & $\begin{array}{l}\text { Number of pills } \\
1-3 \\
4-6\end{array}$ & $\begin{array}{l}4(5.3) \\
6(7.9)\end{array}$ & $\begin{array}{l}34(44.7) \\
32(42.1)\end{array}$ & NS \\
\hline 冚 & $\begin{array}{l}\text { Previous treatment } \\
\text { Yes } \\
\text { No }\end{array}$ & $\begin{array}{l}3(3.9) \\
7(9.2)\end{array}$ & $\begin{array}{l}46(60.5) \\
20(26.3)\end{array}$ & $.01 *$ \\
\hline 氞 & $\begin{array}{l}\text { Accessibility of treatment } \\
\text { Yes } \\
\text { No }\end{array}$ & $\begin{array}{c}9(11.8) \\
1(1.3)\end{array}$ & $\begin{array}{c}55(72.4) \\
11(14.5)\end{array}$ & NS \\
\hline & $\begin{array}{l}\text { Affordability of treatment } \\
\text { Yes } \\
\text { No }\end{array}$ & $\begin{array}{l}7(9.2) \\
3(3.9)\end{array}$ & $\begin{array}{l}61(80.3) \\
5(6.6)\end{array}$ & $.03^{*}$ \\
\hline & $\begin{array}{l}\text { Consultation Cost (Rs.) } \\
\leq 10000 \\
10001-20000\end{array}$ & $\begin{array}{c}9(11.8) \\
1(1.3)\end{array}$ & $\begin{array}{c}60(78.9) \\
6(7.9)\end{array}$ & NS \\
\hline
\end{tabular}




\begin{tabular}{|c|c|c|c|c|}
\hline \multirow{6}{*}{ 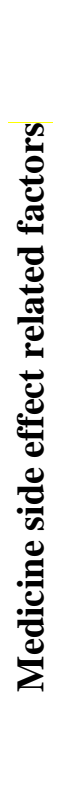 } & $\begin{array}{l}\text { Dizziness } \\
\text { Yes } \\
\text { No }\end{array}$ & $\begin{array}{l}4(5.3) \\
6(7.9)\end{array}$ & $\begin{array}{l}44(57.9) \\
22(28.9)\end{array}$ & NS \\
\hline & $\begin{array}{l}\text { Sedation } \\
\text { Yes } \\
\text { No }\end{array}$ & $\begin{array}{l}7(9.2) \\
3(3.9)\end{array}$ & $\begin{array}{l}45(59.2) \\
21(27.6)\end{array}$ & NS \\
\hline & $\begin{array}{l}\text { GI complication } \\
\text { Yes } \\
\text { No }\end{array}$ & $\begin{array}{l}3(3.9) \\
7(9.2)\end{array}$ & $\begin{array}{l}24(31.6) \\
42(55.3)\end{array}$ & NS \\
\hline & $\begin{array}{l}\text { Weight gain } \\
\text { Yes } \\
\text { No }\end{array}$ & $\begin{array}{l}2(2.6) \\
8(10.5)\end{array}$ & $\begin{array}{l}45(59.2) \\
21(27.6)\end{array}$ & $.003^{*}$ \\
\hline & $\begin{array}{l}\text { Neuromuscular problems } \\
\text { Yes } \\
\text { No }\end{array}$ & $\begin{array}{l}3(3.9) \\
7(9.2)\end{array}$ & $\begin{array}{l}32(42.1) \\
34(44.7)\end{array}$ & NS \\
\hline & $\begin{array}{l}\text { Sexual problems } \\
\text { Yes } \\
\text { No }\end{array}$ & $\begin{array}{l}1(1.3) \\
9(11.8)\end{array}$ & $\begin{array}{c}8(10.5) \\
58(76.3)\end{array}$ & NS \\
\hline \multirow{6}{*}{ 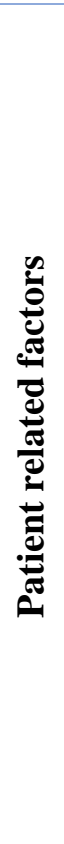 } & $\begin{array}{l}\text { Forgetting to take medicine } \\
\text { Yes } \\
\text { No }\end{array}$ & $\begin{array}{l}3(3.9) \\
7(9.2)\end{array}$ & $\begin{array}{l}37(48.7) \\
29(38.2)\end{array}$ & NS \\
\hline & $\begin{array}{l}\text { Feeling better } \\
\text { Yes } \\
\text { No }\end{array}$ & $\begin{array}{l}6(7.9) \\
4(5.3)\end{array}$ & $\begin{array}{l}47(61.8) \\
19(25.0)\end{array}$ & NS \\
\hline & $\begin{array}{l}\text { Acute illness } \\
\text { Yes } \\
\text { No }\end{array}$ & $\begin{array}{l}2(2.6) \\
8(10.5)\end{array}$ & $\begin{array}{l}9(11.8) \\
57(75.0)\end{array}$ & NS \\
\hline & $\begin{array}{l}\text { Comorbidity } \\
\text { Yes } \\
\text { No }\end{array}$ & $\begin{array}{l}3(3.9) \\
7(9.2)\end{array}$ & $\begin{array}{l}16(21.1) \\
50(65.8)\end{array}$ & NS \\
\hline & $\begin{array}{l}\text { Lack of support } \\
\text { Yes } \\
\text { No }\end{array}$ & $\begin{array}{l}2(2.6) \\
8(10.5)\end{array}$ & $\begin{array}{l}12(15.8) \\
54(71.1)\end{array}$ & NS \\
\hline & $\begin{array}{l}\text { Cultural barrier } \\
\text { Yes } \\
\text { No }\end{array}$ & $\begin{array}{l}3(3.9) \\
7(9.2)\end{array}$ & $\begin{array}{l}17(22.4) \\
49(64.5)\end{array}$ & NS \\
\hline
\end{tabular}

${ }^{*} \mathrm{p}<0.05$ = significant, NS=not significant

Non-compliance was highly associated with treatment related factors: duration of illness up to 15 years (78.9\%), having up to 3 pills (44.7\%), having previous treatment (60.5\%) which was statistically significant $(\mathrm{p}=0.01)$, having accessibility of treatment (80.3\%), having affordability of treatment (80.3\%) which was statistically significant $(\mathrm{p}=0.03)$. Consultation cost up to 1000 was $78.9 \%$. This research study illustrated that different side effects of medication were associated with the non-compliance of medication among BPAD patients. There were high non-compliance with side effects of drugs: dizziness (57.9\%), sedation (59.2\%), weight gain (59.2\%) which is statistically significant ( $\mathrm{p}=0.003)$. There was no association between the side effects: GI complication, neuromuscular problems and 
sexual problems. Patients related factors were associated with forgetting to take medicine (48.7\%) and feeling better (61.8\%). Acute illness, comorbidity, lack of support and cultural barrier were not associated with noncompliance of medication. (Table 4.)

\section{DISCUSSION}

Poor compliance is a problem in all areas of medicine and psychiatry is no exception. ${ }^{8-10}$ Non-Compliance to medication regimens is a serious problem. It has many serious effects on prognosis of the illness and overall effectiveness of health systems. NonCompliant patients are more severely ill at the point of readmission to hospital and have more frequent readmissions. ${ }^{11}$ Simple measures, such as simplifying the drug regimen and giving clear written instructions, are the first step in improving compliance but are not enough for a large number of patients.

This is evident in our study that $76.8 \%$ of the studied BPAD patients were either medium or highly non-compliant with treatment. Study done by Scott and Pope .6 reported noncompliance in around 32\% patients in the previous month. 2 years. However, noncompliance rates of approximately $50 \%$ are commonly reported for patients with BPAD. ${ }^{6,12}$ In a survey of over 2000 psychiatrists, based in eight European countries, the respondents estimated that the majority of patients (57\%) with BPAD were nonadherent or partially adherent to treatment. ${ }^{13}$

There was evidence of patients making decisions about taking medicines based on different factors: patient related factors, treatment related factors and side effects of the drugs related factors. ${ }^{14}$ Our study identified that non-compliance was significantly higher among young mentally ill patients (48.7\%), less than 40 years age group and male patients (52.6\%) this is supported by the study done by Livianos-Aldona et al. ${ }^{15}$ This is also supported by a study done in Qatar which showed that males were more than more likely to be suboptimally (low) adherent when compared to females $(p=0.019) .{ }^{16}$

It was seen in our study that Literacy does not have any impact on the non-compliance (77.6\%) which was statistically significant $(\mathrm{p}=0.033)$. This finding was in contrast to the finding of the study conducted in India. ${ }^{17}$ In consistence with the findings of other studies, ${ }^{18}$ Unemployment (50\%) emerged as the strongest predictor of medication noncompliance $(p=0.047)$ in our study. Financial obstacle or low income (55.3\%) was important problems as reasons for noncompliance. This is in accordance with that reported by other study. ${ }^{19}$ Noncompliance was seen in $78.9 \%$ patients having duration of illness between (1-15 years) in our study similar to the finding by Roy and colleagues in India ${ }^{20}$ which is very obvious since continuing medications for a longer 
duration is difficult for everyone. Many patients in our study reported various sideeffects as the reason for non-compliance. The main medication side effects include dizziness (57.9\%) sedation (59.2\%) and weight gain (59.2\%) which is statistically significant ( $\mathrm{p}=0.003) . \quad$ A prospective study assessed subjective reasons for noncompliance and found that $50 \%$ of patients reported distressed by side effects as a reason for noncompliance similar to the finding of this study.

There were some limitations in this study which include small sample size, and recall bias during self-reporting. Study was confined to a tertiary hospital, so the result may not necessarily represent the general population of the country.

\section{REFERENCES}

1. World Health Organization (WHO). Adherence to long-term therapies: Evidence for action. Geneva: WHO; 2003. [Full Text]

2. Colom F, Vieta E, Tacchi MJ, SanchezMoreno J, Scott J. Identifying and improving non-adherence in bipolar disorders. Bipolar Disord. 2005; 7:24-31. [Pub Med] [Full Text]

3. Lingam $R$, Scott J. Treatment nonadherence in affective disorders. Acta Psychiatr Scand. 2002;105:164-72. [Pub Med] [Full Text]

4. Berk L, Hallam KT, Colom F, Vieta E, Hasty $\mathrm{M}$, Macneil $\mathrm{C}$, et al. Enhancing medication adherence in patients with bipolar disorder. Hum Psychopharmacol. 2010; 25: 1-16 [Pub Med]

\section{CONCLUSION}

Medication non-adherence in patients with BPAD was quite high. This study stresses the critical need for taking necessary steps toward minimizing poor outcomes related noncompliance in drug therapy along with mental health education and proper counselling to the patients.

Acknowledgement: We are thankful to to Universal College of Medical Sciences, Bhairahawa for providing the research grant and support us to conduct this research financially.

5. Busby KK, Sajatovic M. REVIEW: Patient, treatment, and systems-level factors in bipolar disorder nonadherence: A summary of the literature. CNS Neurosci Ther2010; 16: 308-315.

6. Scott J, Pope M. Nonadherence with mood stabilizers: Prevalence and predictors. J Clin Psychiatry. 2002; 63:384-90. [Pub Med]

7. Morisky DE, Ang A, Krousel-Wood M, Ward HJ. Predictive validity of a medication adherence measure in an outpatient setting. J Clin Hypertens (Greenwich). 2008;10(5):348-54. Epub 2008/05/06. [Pub Med] [Full Text]

8. Fenton WS, Blyler CR, Heinssen RK. Determinants of medication compliance in schizophrenia: empirical and clinical findings. Schizophrenia bulletin. 1997;23(4):637-51.

[Pub Med] [Google Scholar] 
9. Razali M, Yahya H. Compliance with treatment in schizophrenia: a drug intervention program in a developing country. Acta Psychiatrica Scandinavica. 1995;91(5):331-5.

10. Cooper $C$, Bebbington $P$, King $M$, Brugha $T$, Meltzer $\mathrm{H}$, Bhugra $\mathrm{D}$, et al. Why people do not take their psychotropic drugs as prescribed: results of the 2000 National Psychiatric Morbidity Survey. Acta Psychiatrica Scandinavica. 2007;116(1):4753 [Pub Med] [Google Scholar]

11. Schumann C, Lenz G, Berghöfer A, MüllerOerlinghausen B. Non-adherence with long-term prophylaxis: a 6-year naturalistic follow-up study of affectively ill patients. Psychiatry research. 1999;89(3):247-57.

[Pub Med] [Full Text]

12. Keck Jr PE, McELROY SL. Outcome in the pharmacologic treatment of bipolar disorder. Journal of clinical psychopharmacology. 1996;16(2):15S23S. [Google Scholar]

13. Vieta $E$, Azorin J-M, Bauer $M$, Frangou $S$, Perugi G, Martinez G, et al. Psychiatrists' perceptions of potential reasons for nonand partial adherence to medication: results of a survey in bipolar disorder from eight European countries. Journal of affective disorders. 2012;143(1-3):125-30.

14. Crowe $M$, Wilson L, Inder M. Patients' reports of the factors influencing medication adherence in bipolar disorderan integrative review of the literature. International journal of nursing studies. 2011;48(7):894-903.

[Pub Med] [Google Scholar]

15. Livianos-Aldana L, Vila-Gomez $M$, RojoMoreno L, Luengo-Lopez M. Patients who miss initial appointments in community psychiatry? A Spanish community analysis. International Journal of Social Psychiatry. 1999;45(3):198-206. [Google Scholar]
16. Bener A, Dafeeah EE, Salem MO. A study of reasons of non-compliance of psychiatric treatment and patients' attitudes towards illness and treatment in Qatar. Issues in mental health nursing. 2013;34(4):273-80. [Pub Med]

17. Maan $C$, Munnawar Hussain M, Heramani $N$, Lenin R. Factors affecting noncompliance among psychiatric patients in the Regional Institute of Medical Sciences, Imphal. IOSR J Pharm. 2015;5(1):1-5. [Google Scholar]

18. Mahaye S, Nkosi S, Mahomed FN, Ntuli L, Pramlal J, Setlhabana O, et al. Medication adherence of psychiatric patients in an outpatient setting. African Journal of pharmacy and pharmacology. 2012;6(9):608-12.

19. Kassis IT, Ghuloum S, Mousa H, Bener A. Treatment non-compliance of psychiatric patients and associated factors: are patients satisfied from their psychiatrist? British Journal of Medicine and Medical Research. 2014;4(2):785.

[Google Scholar]

20. Roy R, Jahan M, Kumari S, Chakraborty P. Reasons for drug non-compliance of psychiatric patients: A centre based study. Journal of the Indian Academy of Applied Psychology. 2005;31(1-2):24-8.

[Google Scholar]

21. Loffler W., Kilian R., Toumi M., Angermeyer M. (2003) Schizophrenic patients' subjective reasons for compliance and noncompliance with neuroleptic treatment. Pharmacopsychiatry 36: 105-112. [Pub Med] [Google Scholar] 